\section{Czech universities go slow}

Prague \& Brno. Czech universities have not enthusiastically embraced the opportunity to reform themselves along Western lines. On the contrary, apart from a few pockets of individuals, they have been steadfastly resistant to change. In the past four years, there have been fierce confrontations between universities and government.

Confrontation is now being defused, and democracy nudged along, with the help of electronic technology. Remarkably, the development of the new and much disputed university law, which is now going through parliament, was conducted by email; anyone at any time could watch its progress and make their own comments.

The new law

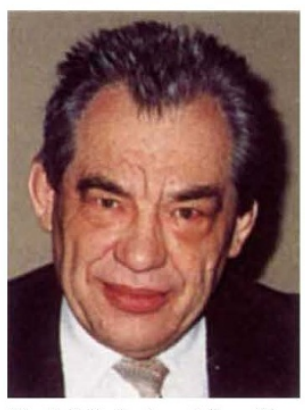
Ondráč ek: backing the reforms.
Research was strongly discouraged and all but disappeared.

Small wonder that the reaction against this repression after the 1989 velvet revolution, known simply as "the November" by Czechs, was sometimes more emotional than rational.

In a rush of enthusiasm, the first democratically elected government of Czechoslovakia, as one of its first acts in 1990, passed a law giving universities complete autonomy. But the law also introduced an unworkable level of democracy into universities, by giving too much power to faculty deans and too little to rectors. At a time when tough decisions had to be made about staffing levels, about the competence of teaching staff and about general structural reforms, deans were too close to their faculty staff to be able to carry through decisions, while rectors, themselves not always totally reform-minded, right to tell them to be tougher.

Internal assessments of the suitability of individual staff members for their jobs were mostly formalities and nothing changed. There has been little turnover of staff in the past four years. In fact, staff numbers have risen from 11,216 in 1990 to 13,463 in 1993 , because one new university was founded.

But university staffs are weary of change, weary of the stress of constant assessment and competition - a lifestyle they are not used to. Recent elections for new university rectors reflect this depression. Overwhelmingly, rectors pledging to resist further reforms were elected.

Impatient of the universities' conservatism, the government tried in the summer of 1993 to force the issue by passing a "small amendment" to the 1990 universities act. This required all permanent staff members to be put on shortterm contracts, to expire in September 1994, before which time each would be required to compete for his or her own job. Formal concorsi were held in the first six months of this year. In future, according to the new universities bill, only professors will have tenure.

To the frustration of the government and academy scientists, and to the glee of university staff who regarded the "small amendment" as an intolerable intrusion of the state on their autonomy, the move did not work.

Eduard Schmidt, rector of Masaryk University in the Moravian capital of Brno, $200 \mathrm{~km}$ south-east of Prague, describes the amendment as "a terrible thing - imagine, I was rector of the university, but I had no contract".

"But", he says, "we Czechs have experience in surviving. We had to survive the Austrian empire, Hitler, the communists...". In this spirit, most universities got round the amendment by exploiting the one-month delay between its enactment them, if they wish, to push through reforms without being overruled by deans and academic senates. It also introduces student fees, a development that has been hard for universities to swallow, but they will now probably be set at a fairly low level.

The new law firmly re-establishes the principle that universities should carry out research and sets up a new, government accreditation committee, whose responsibilities will include the reassessment of the status of the Czech Republic's 23 universities. The committee will recommend that those not carrying out research be regraded as technical colleges. The law formally introduces a $\mathrm{PhD}$ system and rules that degrees will be given by the universities rather than by the Academy .

Emanuel Ondráček, vice-minister for universities and research, thinks that the long battle to achieve some sort of compromise is over and that the bill will be passed by next spring, in time for the next academic year. He may, however, find his bill delayed by other governmental priorities.

It is not surprising that Czech universities are deeply conservative and protectionist. Czechoslovak universities bore the brunt of the communists' ideological assault on academic institutions. For 40 years - a whole generation - the universities were forced to abandon their traditions of free intellectual thought and instead had to kowtow to the marxist line.

\title{
Who should give PhDs?
}

IN the Soviet model, imposed on Czechoslovakia in the early 1950 s, the research degree was called Candidate of Science. It was similar to a PhD, but its criteria were less uniform and standards generally lower.

Ever since the velvet revolution, Czech academics have been keen to move to the Western PhD system for research degrees. In many places, PhD programmes have already started in anticipa tion of the provisions of the new bill on higher education now going through parliament. The Candidate of Science degree was finally laid to rest last year; scientists already part of the way through their programmes will be allowed to finish, but they may find that their certificates have little value.

But agreement that PhDs should be introduced has not been matched by consensus about who should award them. Before 1990, both universities and the Academy of Sciences trained students for their Candidate of Science degree, and both awarded them. In practice, most were awarded by the academy because almost all research was done there.

The ministry of education and science is now planning to take this privilege away from the academy, on the grounds that universities should have sole charge of education. The academy, with its battery of relatively well-equipped research institutes and experienced research staff, will continue its deep involvement in practical training, but will no longer be responsible for the theoretical training.

Academy staff are profoundly disappointed that the decision about the awarding of PhDs, long awaited and still hotly disputed, has finally favoured the universities. Although the academy presidium is resigned to the situation, others continue to be furious. "It's like telling athletes that they can train newcomers, but they can't send them to the Olympics", complains Petr Boček, head of the academy's Institute of Analytical Chemistry in Brno, who also deeply resents what he feels to be the "violent and bad way" the academy's rights were taken away.

He speaks for many critics of the plan, who believe that the government wants to adopt a system appropriate in Western Europe, where universities always had a strong research history and had always awarded PhDs, onto the Czech academic system, ignoring the very different history in central Europe. 